DOI: $10.15193 /$ zntj/2017/111/189

\author{
ALEKSANDRA M. KOCOT, MONIKA S. MRUK, \\ MAGDALENA A. OLSZEWSKA
}

\title{
FLUORESCENCYJNA HYBRYDYZACJA IN SITU W IDENTYFIKACJI I OCENIE AKTYWNOŚCI FIZJOLOGICZNEJ LACTOBACILLUS SPP. W SOKU Z JAGÓD GOJI
}

\begin{abstract}
Streszczenie
W związku z popularyzacją trendu „Super Food” konsumenci oczekują obecności na rynku produktów o szerokim spektrum oddziaływania na organizm człowieka. Sok z jagód goji charakteryzuje się wieloma dobroczynnymi właściwościami, a wzbogacenie go w potencjalnie probiotyczne kultury Lactobacillus spp. może dodatkowo zwiększyć jego wartość biologiczną pod warunkiem zachowania przez szczepy żywotności. Celem pracy była identyfikacja i ocena aktywności fizjologicznej komórek Lactobacillus spp. w soku z jagód goji z zastosowaniem metody fluorescencyjnej hybrydyzacji in situ (FISH). W celu identyfikacji Lactobacillus spp. przeprowadzono hybrydyzację z sondami oligonukleotydowymi rRNA, w tym z sondą dla domeny Eubacteria (Eub338), nonsensowną (Non338), a także dla grupy bakterii fermentacji mlekowej (Lab158) i 11 sond specyficznych dla różnych gatunków z rodzaju Lactobacillus. Analizę aktywności fizjologicznej komórek Lactobacillus spp. w soku z jagód goji przeprowadzono sondą Eub338 bezpośrednio po zaszczepieniu oraz 3., 8., 15., 22. i 29. dnia przechowywania w temp. $20{ }^{\circ} \mathrm{C}\left( \pm 2{ }^{\circ} \mathrm{C}\right)$ oraz $6{ }^{\circ} \mathrm{C}$ i porównano z wynikami metody płytkowej. Metoda FISH pozwoliła na określenie przynależności gatunkowej $8 \mathrm{z} 9$ badanych szczepów, które zaklasyfikowano do L. plantarum oraz L. brevis. Wykazano ponadto, że w wyniku przechowywania soku z jagód goji w temp. $20^{\circ} \mathrm{C}\left( \pm 2{ }^{\circ} \mathrm{C}\right)$ aktywność fizjologiczna komórek podlegała znacznym zmianom, czyli zmniejszyła się w ostatnim dniu przechowywania i po porównaniu z wynikami metody płytkowej można wskazać na stan niehodowalności komórek. Natomiast po przechowywaniu w temp. $6{ }^{\circ} \mathrm{C}$ aktywność fizjologiczna była stabilna, gdyż liczba komórek utrzymywała się na wysokim poziomie do ostatniego dnia przechowywania. Badania przeprowadzone w tym zakresie wskazują na przydatność metody FISH w detekcji i poznawaniu fizjologii pałeczek Lactobacillus spp.
\end{abstract}

Słowa kluczowe: Lactobacillus spp., fluorescencyjna hybrydyzacja in situ, identyfikacja, aktywność fizjologiczna

Mgr A.M. Kocot, mgr M.S. Mruk, dr M.A. Olszewska, Katedra Mikrobiologii Przemystowej i Żywności, Wydz. Nauki o Żywności, Uniwersytet Warmińsko-Mazurski $w$ Olsztynie, Pl. Cieszyński 1, 10-726 Olsztyn.Kontakt: magdalena.olszewska@uwm.edu.pl 


\section{Wprowadzenie}

Fluorescencyjna hybrydyzacja in situ (FISH) jest dobrze poznana w kontekście identyfikacji drobnoustrojów, ma jednak szersze spektrum aplikacji, jak np. analizę aktywności fizjologicznej komórek drobnoustrojów [17]. W tym przypadku FISH umożliwia detekcję komórek bez względu na to, czy są hodowalne, czy nie i pozwala porównać sygnał z FISH z tempem wzrostu komórek. W metodzie stosowane są sondy, czyli krótkie $(15 \div 30)$ sekwencje oligonukleotydowe znakowane barwnikami fluorescencyjnymi w pozycji 5', które hybrydyzują z komplementarnymi sekwencjami rRNA komórek bakteryjnych [3,6]. Intensywność fluorescencji komórek może być zatem wykorzystana jako wskaźnik ogólnej aktywności fizjologicznej, ponieważ w trakcie wzrostu jest on sprzężony z wydajnością syntezy białek i w związku z tym liczbą rybosomów zawierających rRNA [7]. Potencjał FISH jako odpowiednika aktywności fizjologicznej komórek zależy jednak od szybkości dekompozycji rRNA po śmierci komórek, na którą wpływ ma poziom enzymów katalizujących rozpad RNA - RNAz oraz stopień permeabilizacji błon cytoplazmatycznych [17].

Rozszerzenie asortymentu żywności o tzw. żywność „Super Food” jest wynikiem zwiększonego zapotrzebowania konsumenta na żywność funkcjonalną, czyli pełniącą wielorakie funkcje w organizmie człowieka. Szczególnie ważny jest aspekt prozdrowotny żywności. Jedną z naturalnych i szeroko dostępnych form takiej żywności są produkty fermentowane, a wśród nich fermentowane soki warzywne i warzywnoowocowe. Coraz większą popularnością cieszą się także soki z owoców w Polsce niespotykanych, jak np. z jagód goji. Owoce te pochodzą z Chin, Tybetu oraz Mongolii i zaliczane są do tzw. ,super żywności”. W medycynie azjatyckiej dobroczynne właściwości tych owoców znane są od 2300 lat [13]. Charakteryzują się wysoką zawartością witaminy C, szeregiem witamin z grupy B i związków mineralnych. Jagody goji są także bogatym źródłem polifenoli, czyli bioaktywnych związków o właściwościach antyoksydacyjnych, spośród których wymienić można kwercetynę, rutynę, kwas kawowy i kwas chlorogenowy [16]. Wysoką aktywność antyoksydacyjną owoce te zawdzięczają również kompleksowi LBP (Lycium Barbarum Polysaccharides), który stymuluje układ odpornościowy $[1,21]$. Ponadto aktywność tego kompleksu opóźnia procesy starzenia się organizmu, a także hamuje objawy wielu stanów chorobowych [1].

Celem pracy była identyfikacja izolatów pałeczek fermentacji mlekowej z zastosowaniem FISH, a także zastosowanie tej metody w ocenie aktywności fizjologicznej Lactobacillus spp. w soku z jagód goji podczas 29-dniowego przechowywania w temp. $20{ }^{\circ} \mathrm{C}\left( \pm 2{ }^{\circ} \mathrm{C}\right)$ i w $6{ }^{\circ} \mathrm{C}$. Aktywność fizjologiczną komórek określono bezpośrednio po zaszczepieniu oraz 3., 8., 15., 22. i 29. dnia przechowywania i porównano z wynikami metody płytkowej. 


\section{Materiały i metody badań}

Materiał doświadczalny stanowiło 9 izolatów pałeczek fermentacji mlekowej, z których 8 wyizolowano z piekarskich razowych zakwasów żytnich pochodzących $z$ różnych regionów Polski i jeden z kiszonych ogórków (nr 5.1). Bakterie te poddano fluorescencyjnej hybrydyzacji in situ z użyciem sond oligonukleotydowych znakowanych fluorescencyjnie (Bionovo). Zastosowano sondę dla domeny Eubacteria: 5' GCT GCC TCC CGT AGG AGT 3' znakowana cyjaniną 3 (Eub338) [2], jako kontrolę negatywną zastosowano sondę nonsensowną: 5' ACT CCT ACG GGA GGC AGC 3' znakowana cyjaniną 3 (Non338) [25], sondę dla bakterii fermentacji mlekowej: 5' GGT ATT AGC AYC TGT TTC CA 3' znakowana cyjaniną 3 (Lab158) [3] oraz 11 sond specyficznych dla różnych gatunków z rodzaju Lactobacillus: L. brevis: 5' CAT TCA ACG GAA GCT CGT TC 3' znakowana cyjaniną 3 (Lbre) [4], L. casei/L. paracasei: 5' GTT CCA TGT TGA ATC TCG G 3' znakowana cyjaniną 5 (Lpara) [4], $L$. hilgardii: 5' CAA CTT CAT TGA CCA AGA CGCG 3' znakowana cyjaniną 5 (Lhilg) [4], L. plantarum: 5' CCA ATC AAT ACC AGG AGT TCG 3' znakowana cyjaniną 3 (Lplan) [4], L. plantarum: 5' CCG TCA ATA CCT GAA CAG 3' znakowana cyjaniną 3 (LbpV3) [10], L. curvatus: 5' ATG ATA ATA CCC 3' znakowana cyjaniną 3 (Lcur) [6]; L. fermentum: 5' GCG ACC AAA ATC AAT CAG G 3' znakowana cyjaniną 3 (Lbfr) [23], L. sanfranciscensis: 5' TAA GAA TCA ATT GGG CGA C 3' znakowana cyjaniną 3 (Lbsa) [24], L. acidophilus: 5' TCT TTC GAT GCA TCC ACA 3' znakowana cyjaniną 3 (Lba) [24], L. amylovorus: 5' GTA AAT CTG TTG GTT CCG C 3' znakowana cyjaniną 3 (Lbam) [9], L. delbrueckii: 5' AAG GAT AGC ATG TCT GCA 3' znakowana 6-karboksyfluoresceiną - 6-FAM (Lbd) [12]. Szczepy przechowywano w mikrobankach (Microbank ${ }^{\mathrm{TM}}$, Pro-Lab Diagnostics), natomiast uaktywniano w pożywce MRS-bulion (Merck) po $24 \mathrm{~h}$ hodowli w temp. $30^{\circ} \mathrm{C}$. Uaktywnione szczepy stosowano do zaszczepiania $50 \mathrm{ml}$ soku z jagód goji w postaci $3 \%$ inokulum. W badaniach zastosowano 100-procentowy pasteryzowany sok bez dodatku cukru firmy EkaMedica. Soki przechowywano przez 29 dni w dwóch wariantach temperaturowych - w temp. $20^{\circ} \mathrm{C}\left( \pm 2{ }^{\circ} \mathrm{C}\right)$ oraz w $6{ }^{\circ} \mathrm{C}$. Próbki soku pobierano bezpośrednio po zaszczepieniu oraz 3., 8., 15., 22. i 29. dnia przechowywania i wykonywano analizę ilościową z zastosowaniem FISH i sondy Eub338 znakowanej cyjaniną 3 oraz posiewów płytkowych. Ta sama procedura FISH posłużyła identyfikacji oraz ocenie ilościowej komórek bakteryjnych w poszczególnych dniach przechowywania soku z jagód goji. Komórki bakteryjne osadzone na filtrach (Ø $13 \mathrm{~mm}, 0,22 \mu \mathrm{m}$; Isopore, Millipore, Darmstadt, Germany) z zastosowaniem wieży filtracyjnej (Merck Millipore) poddawano hybrydyzacji z sondami w następujących warunkach: temp. $48{ }^{\circ} \mathrm{C}, 3 \mathrm{~h}$. Następnie wypłukiwano nadmiar sondy $\left(48{ }^{\circ} \mathrm{C}, 15 \mathrm{~min}\right)$ i zabarwiano DAPI (4',6-diamidyno-2-fenyloindolem, $1 \mathrm{mg} / \mathrm{ml}, 5 \mathrm{~min}$, temp. $20^{\circ} \mathrm{C}\left( \pm 2{ }^{\circ} \mathrm{C}\right)$, bez dostępu światła), po czym przygotowywano preparaty mikroskopowe. Analizy preparatów 
wykonywano przy użyciu mikroskopu epifluorescencyjnego (Olympus BX51), zaopatrzonego we właściwe zestawy filtrów oraz kamerę Digital Colour XC10 (Olympus). Do analizy obrazu i zliczania komórek posłużył programu cellSens Dimension 1.5 (Olympus). Komórki liczono z 10 obrazów mikroskopowych, a wyniki wyrażano w $\log$ kom. $/ \mathrm{ml}$. Posiewy powierzchniowe w dwóch powtórzeniach z odpowiednich dziesięciokrotnych rozcieńczeń soku wykonywano na podłoże MRS-agar (Merck) i poddawano inkubacji w temp. $30{ }^{\circ} \mathrm{C}$ w warunkach beztlenowych (Anaerocult ${ }^{\mathbb{B}} \mathrm{C}$, Merck) przez 48 h. Po tym czasie liczono kolonie, a wynik wyrażano w log jtk/ml.

\section{Wyniki i dyskusja}

Wszystkie badane izolaty zaklasyfikowano do pałeczek fermentacji mlekowej (Lab158+). Spośród 9 szczepów 5 określono jako Lactobacillus plantarum (Lplan/LbpV3+), 3 - jako Lactobacillus brevis (Lbrev+), a 1 pozostał taksonomicznie przypisany jedynie do poziomu rodzaju (tab. 1). Przynależność określano na podstawie występowania sygnału fluorescencyjnego po hybrydyzacji ze specyficzną sondą w odniesieniu do kontroli negatywnej i porównaniu z sygnałem barwnika DAPI (fot. 1 i 2). Przydatność metody FISH do identyfikacji bakterii fermentacji mlekowej z fermentowanych surowców pochodzenia roślinnego opisano we wcześniejszych badaniach [19]. Po zastosowaniu tych samych sond również zidentyfikowano dwa typowe dla surowców roślinnych gatunki, L. plantarum i L. brevis. Ponadto Blasco i wsp. [4] zastosowali FISH z użyciem sond specyficznych dla różnych gatunków z rodzajów Lactobacillus, Leuconostoc, Pediococcus i Oenococcus na izolatach pochodzących z moszczu i wina. Oceniono specyficzność sond i wykazano, że za wadliwą fermentację wina odpowiadał Oenococcus oeni, natomiast wysoki poziom amin biogennych w winie najprawdopodobniej spowodowany był obecnością gatunku Lactobacillus brevis. Metoda FISH została także zastosowana w badaniach różnorodności i rozmieszczenia pałeczek fermentacji mlekowej w serze Stilton [10]. Oprócz sondy dla domeny Eubacteria wykorzystano sondy dla gatunków Lactobacillus lactis i Lactobacillus plantarum, których rozkład przestrzenny różnił się w zależności od warstwy sera. Biorąc powyższe pod uwagę, potencjał metody FISH nie jest jeszcze wyczerpany. Projektowanie nowych sond dla licznych gatunków z rodzaju Lactobacillus oraz znalezienie ich nowych zastosowań w badaniach żywności to zagadnienia ciągle niezbadane.

Ocena aktywności fizjologicznej pozwoliła wykazać dobrą przeżywalność szczepów Lactobacillus spp. w soku z jagód goji (rys. 1 i 2). Po przechowywaniu w temp. $6{ }^{\circ} \mathrm{C}$ zaobserwowano niewielki przyrost populacji Lactobacillus spp. do 8. dnia (rys. 1A, rys. 1B), czyli średnio z 8,09 do 8,32 jednostek logarytmicznych w $1 \mathrm{ml}$ (metoda płytkowa) i z 8,11 do 8,35 jednostek logarytmicznych w $1 \mathrm{ml}$ soku (FISH) (rys. 1C). W ostatnim dniu przechowywania średnia liczba komórek nie obniżyła się poniżej 7,70 
jednostek logarytmicznych w $1 \mathrm{ml}$ (FISH). Po przechowywaniu w temp. $20^{\circ} \mathrm{C}\left( \pm 2{ }^{\circ} \mathrm{C}\right)$ wzrost Lactobacillus spp. następował szybciej, gdyż maksymalny przyrost populacji oznaczono w 3. dniu (rys. 2A, rys. 2B). Liczba komórek w porównaniu z oznaczeniem początkowym zwiększyła się średnio o 1,13 i 1,11 jednostki logarytmicznej w $1 \mathrm{ml}$ soku odpowiednio: w przypadku metody FISH i metody płytkowej (rys. 2C). Największy wzrost w 3. dniu przechowywania osiągnął szczep Lactobacillus sp. 3.3, gdyż liczba tych bakterii zwiększyła się o 1,38 jednostki logarytmicznej w porównaniu z oznaczeniem początkowym i wartość ta kształtowała się na poziomie 9,29 jednostek logarytmicznych w $1 \mathrm{ml}$ (metoda płytkowa) (rys. 2A). Również z zastosowaniem metody FISH największy przyrost odnotowano w 3. dniu przechowywania w soku z Lactobacillus sp. 3.3. Przyrost wynosił 1,38 jednostki logarytmicznej, a liczba komórek to 9,30 jednostek logarytmicznych w $1 \mathrm{ml}$ badanej próbki soku (rys. 2B). Od 3. dnia liczba komórek zaczęła zmniejszać się i 29 . dnia była na poziomie $<5$ jednostek logarytmicznych, bez względu na szczep (metoda płytkowa). Natomiast metodą FISH oznaczono inne wartości 15., 22. i 29. dnia przechowywania, średnio różniące się względem metody płytkowej kolejno o: 1,79, 2,12 i 1,47 jednostki logarytmicznej w $1 \mathrm{ml}$ soku (rys. 2C). Różnice te wskazują na stan VBNC (ang. viable but nonculturable) komórek, czyli utratę hodowalności tych drobnoustrojów w zadanych warunkach [18].

Tabela 1. Wyniki identyfikacji szczepów wyizolowanych z żywności z zastosowaniem fluorescencyjnej hybrydyzacji in situ

Table 1. Identification results of strains isolated from food with fluorescence in situ hybridization

\begin{tabular}{|c|c|c|c|c|c|c|c|c|c|c|c|c|c|c|}
\hline $\begin{array}{c}\text { Badany } \\
\text { szczep } \\
\text { Tested strain } \\
\end{array}$ & Eub338 & Non338 & Lab157 & Lplan & LbpV3 & Lbrev & Lpara & Lhilg & Lba & Lbam & Lbsa & Lbfr & Lcur & Lbd \\
\hline $\begin{array}{c}\text { L. plantarum } \\
1.1\end{array}$ & + & - & + & + & + & - & - & - & - & - & - & - & - & - \\
\hline $\begin{array}{c}\text { L. plantarum } \\
2.1 \\
\end{array}$ & + & - & + & + & + & - & - & - & - & - & - & - & - & - \\
\hline $\begin{array}{c}\text { L. plantarum } \\
3.1 \\
\end{array}$ & + & - & + & + & + & - & - & - & - & - & - & - & - & - \\
\hline L. brevis 3.2 & + & - & + & - & - & + & - & - & - & - & - & - & - & - \\
\hline $\begin{array}{c}\text { Lactobacillus } \\
\text { sp. } 3.3\end{array}$ & + & - & + & - & - & - & - & - & - & - & - & - & - & - \\
\hline L. brevis 3.4 & + & - & + & - & - & + & - & - & - & - & - & - & - & - \\
\hline L. brevis 4.1 & + & - & + & - & - & + & - & - & - & - & - & - & - & - \\
\hline $\begin{array}{c}\text { L. plantarum } \\
4.2\end{array}$ & + & - & + & + & + & - & - & - & - & - & - & - & - & - \\
\hline $\begin{array}{l}\text { L. plantarum } \\
5.1\end{array}$ & + & - & + & + & + & - & - & - & - & - & - & - & - & - \\
\hline
\end{tabular}




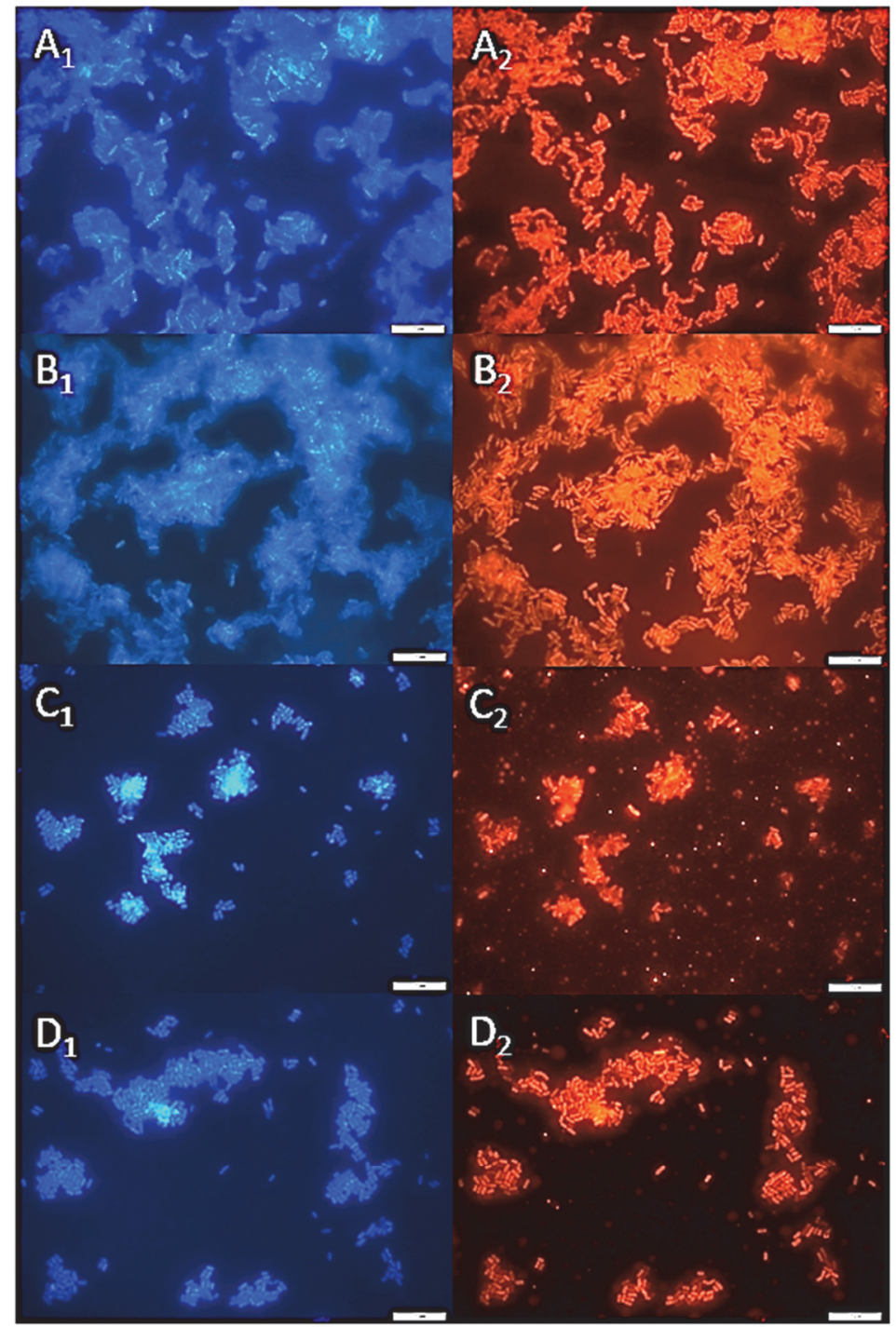

Fot. 1. Fluorescencyjna hybrydyzacja in situ Lactobacillus plantarum 1.1; komórki barwione DAPI [ $\mathrm{A}_{1}$, $\mathrm{B}_{1}, \mathrm{C}_{1}, \mathrm{D}_{1}$; ; komórki po hybrydyzacji z sondą Eub338 [ $\left.\mathrm{A}_{2}\right]$; komórki po hybrydyzacji z sondą Lab158 $\left[\mathrm{B}_{2}\right]$; komórki po hybrydyzacji z sondą Lplan $\left[\mathrm{C}_{2}\right]$; komórki po hybrydyzacji z sondą $\mathrm{LbpV} 3\left[\mathrm{D}_{2}\right]$

Photo 1. Fluorescent in situ hybridization of Lactobacillus plantarum 1.1; cells stained with DAPI [ $\mathrm{A}_{1}$, $\left.\mathrm{B}_{1}, \mathrm{C}_{1}, \mathrm{D}_{1}\right]$; cells hybridized with Eub338 probe $\left[\mathrm{A}_{2}\right]$; cells hybridized with Lab158 probe $\left[\mathrm{B}_{2}\right]$; cells hybridized with Lplan probe $\left[\mathrm{C}_{2}\right]$; cells hybridized with LbpV3probe $\left[\mathrm{D}_{2}\right]$ 


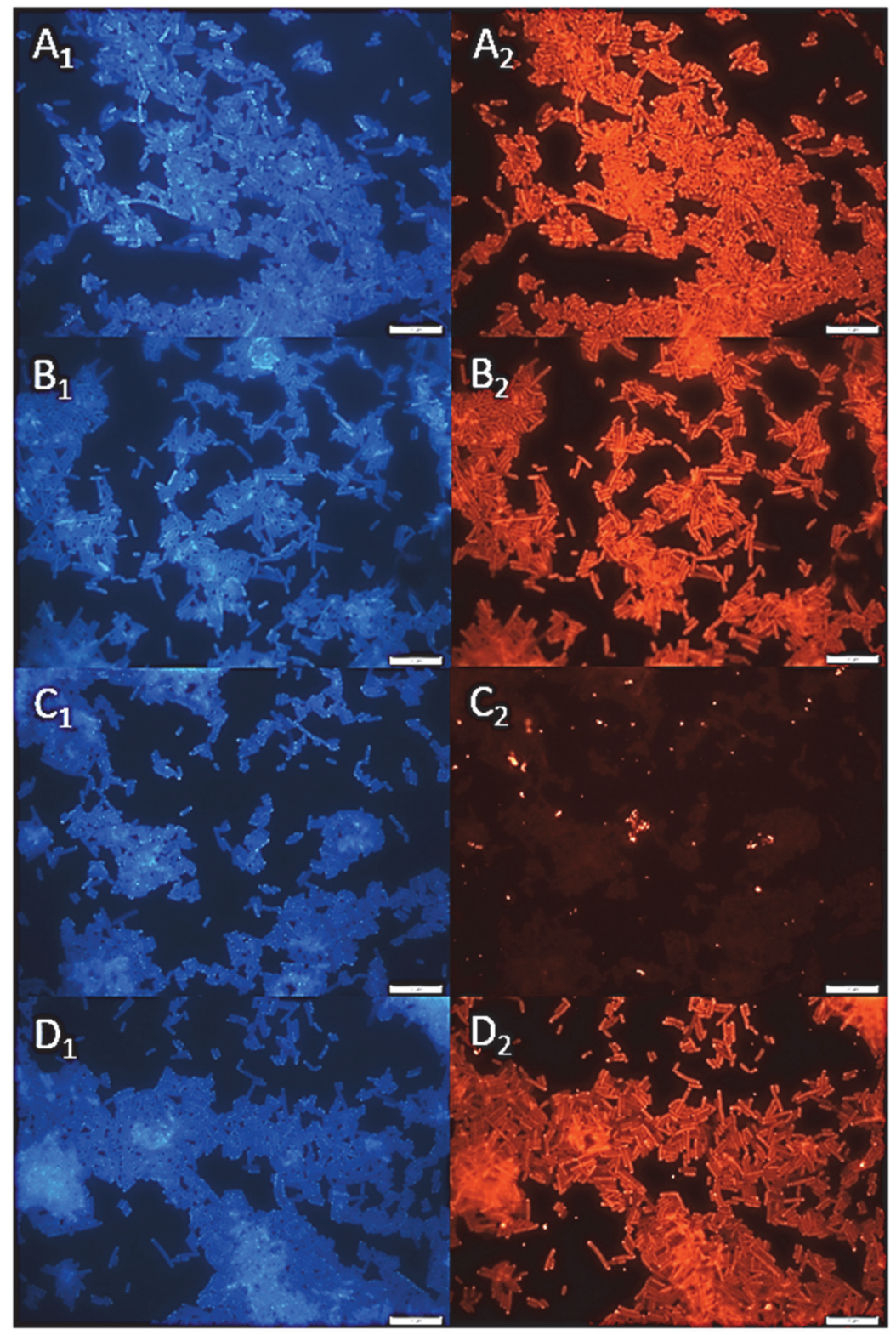

Fot. 2. Fluorescencyjna hybrydyzacja in situ Lactobacillus brevis 3.2; komórki barwione DAPI $\left[\mathrm{A}_{1}, \mathrm{~B}_{1}\right.$, $\left.\mathrm{C}_{1}, \mathrm{D}_{1}\right]$; komórki po hybrydyzacji z sondą Eub338 [ $\left.\mathrm{A}_{2}\right]$; komórki po hybrydyzacji z sondą Lab158 $\left[\mathrm{B}_{2}\right]$; komórki po hybrydyzacji z sondą LbpV3 $\left[\mathrm{C}_{2}\right]$; komórki po hybrydyzacji z sondą Lbrev $\left[\mathrm{D}_{2}\right]$

Photo 2. Fluorescent in situ hybridization of Lactobacillus brevis 3.2; cells stained with DAPI $\left[\mathrm{A}_{1}, \mathrm{~B}_{1}, \mathrm{C}_{1}\right.$, $\left.\mathrm{D}_{1}\right]$; cells hybridized with Eub338 probe $\left[\mathrm{A}_{2}\right]$; cells hybridized with Lab158 probe $\left[\mathrm{B}_{2}\right]$; Lactobacilli cells hybridized with $\mathrm{LbpV} 3$ probe $\left[\mathrm{C}_{2}\right]$; cells hybridized with Lbrev probe $\left[\mathrm{D}_{2}\right]$ 


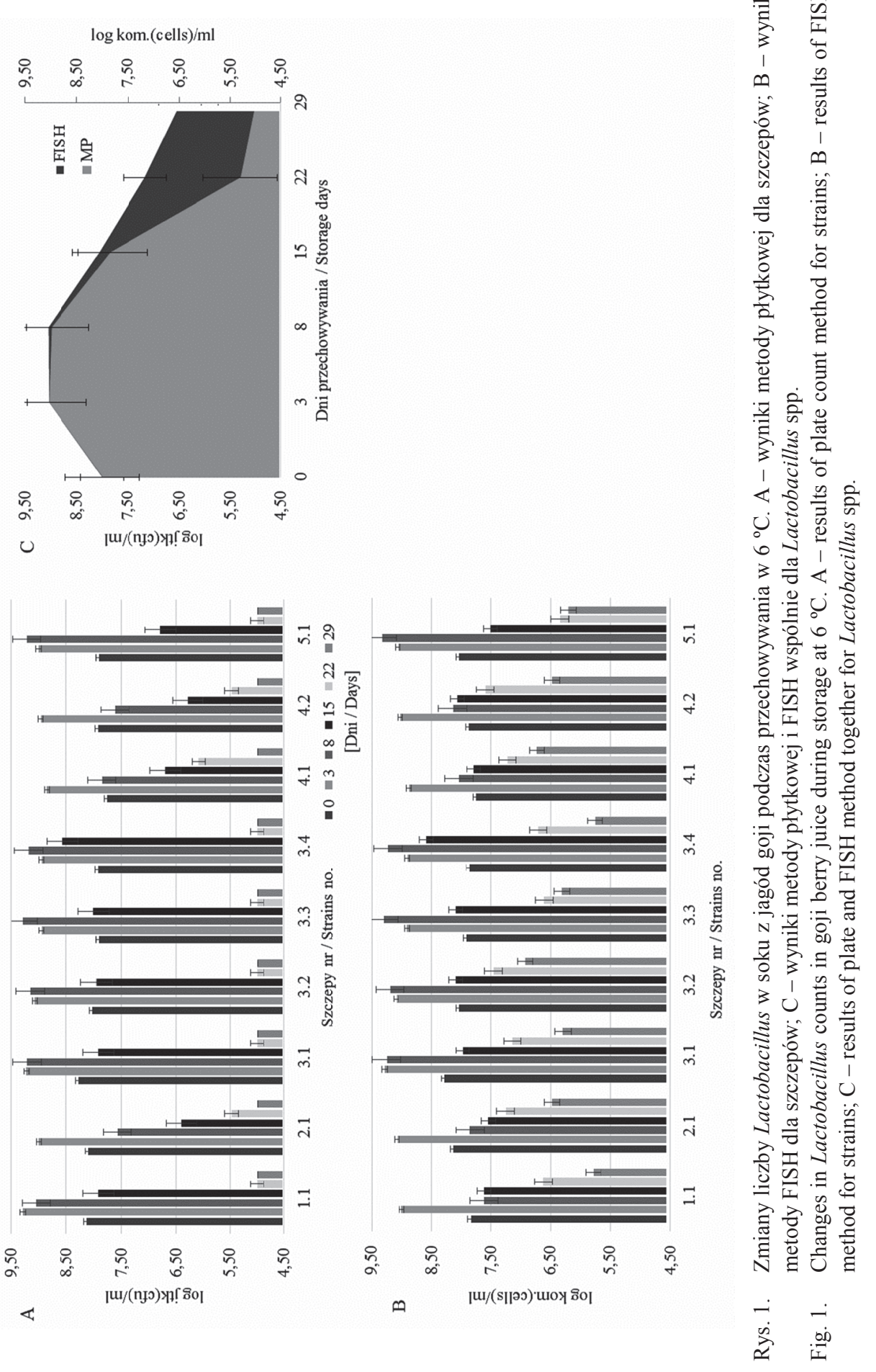




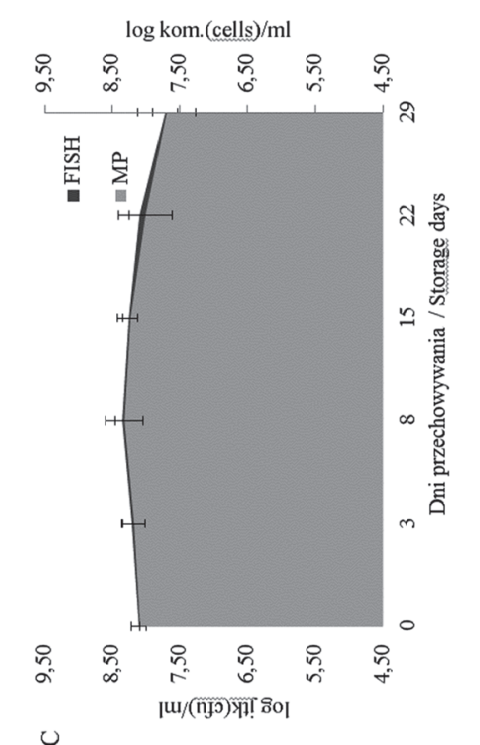

㠃

$\pi$

$\frac{\pi}{8}$

t

궁

के

है

है

Oे

N

茾学 1

4 《

ते 0

$33 N$

贾

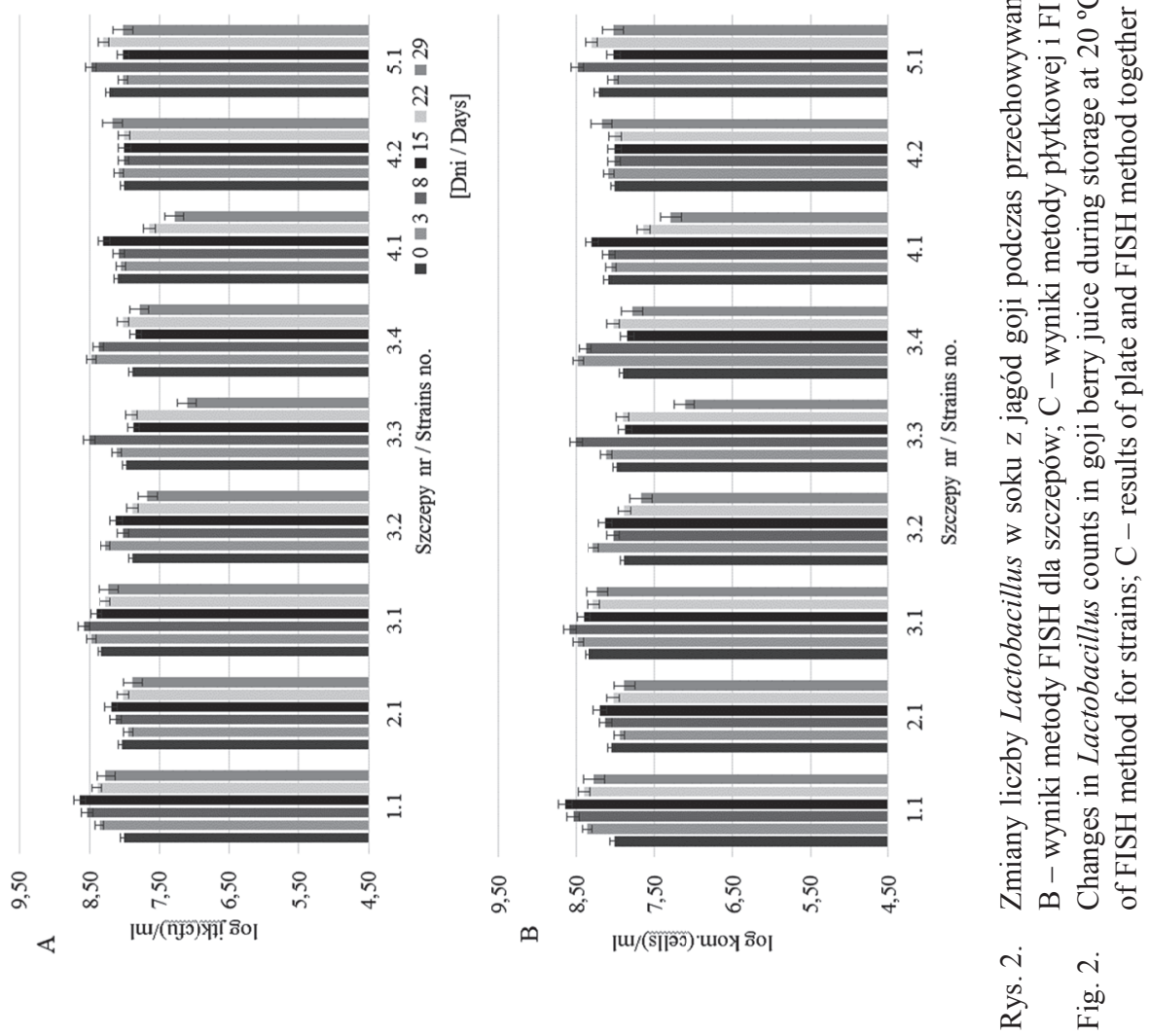


Zmiana stanu fizjologicznego komórek w temp. $20^{\circ} \mathrm{C}\left( \pm 2{ }^{\circ} \mathrm{C}\right)$ nastąpiła po szybkim rozwoju populacji do ponad 9 jednostek logarytmicznych, wynikiem czego było brunatnienie soku. Następnie zaobserwowano zamieranie populacji wywołane czynnikami stresowymi, np. wyczerpaniem składników odżywczych soku i tym samym obniżenie aktywności i hodowalności. Natomiast w niskiej temperaturze, wymagającej zaadaptowania się komórek w temp. $6{ }^{\circ} \mathrm{C}$, rozwój oraz zamieranie populacji były mniejsze i spowolnione, osiągając stabilność w środowisku soku z jagód goji.

Badania przeżywalności szczepów z rodzaju Lactobacillus w soku prowadzili także Young i wsp. [23], którzy zbadali przeżywalność szczepów Lactobacillus acidophilus LA39, Lactobacillus plantarum C3, Lactobacillus casei A4 i Lactobacillus delbrueckii $\mathrm{D} 7 \mathrm{w}$ fermentowanym soku pomidorowym podczas 4 tygodni przechowywania w temp. $4{ }^{\circ} \mathrm{C}$. Analizy ilościowej dokonali z zastosowaniem metody płytkowej. W przypadku szczepów Lactobacillus acidophilus LA39 i Lactobacillus delbrueckii D7 liczby komórek zmieniły się nieznacznie i wyniosły odpowiednio: 9,15 i 8,91 jednostek logarytmicznych w $1 \mathrm{ml}$ soku. Szczep Lactobacillus casei A4 wykazał stosunkowo dużą przeżywalność i w 4. tygodniu liczba komórek była na poziomie 8,23 jednostek logarytmicznych w $1 \mathrm{ml}$. Zaobserwowano, że spośród badanych szczepów Lactobacillus plantarum C3 wykazał najmniejszą przeżywalność, gdyż liczba komórek w ostatnim tygodniu przechowywania soku wyniosła 3,40 jednostek logarytmicznych w $1 \mathrm{ml}$. Pereira i wsp. [20] zbadali przeżywalność szczepu Lactobacillus casei w soku z jabłek nanercza w temp. $4{ }^{\circ} \mathrm{C}$ przez 42 dni. Oznaczenia ilościowe wykonali metodą płytkową. Wykazali, że liczba komórek do 21. dnia zwiększyła się z 8,41 do 8,72 jednostek logarytmicznych w $1 \mathrm{ml}$, a od 35. dnia następowało powolne ich zamieranie, gdyż liczba komórek obniżyła się do 8,62 jednostek logarytmicznych w $1 \mathrm{ml}$ soku. Pomimo stopniowego zamierania populacji, liczba komórek oznaczona w ostatnim dniu nie obniżyła się poniżej 8 jednostek logarytmicznych w $1 \mathrm{ml}$. Z kolei Yoon i wsp. [22] poddali fermentacji sok z kapusty przez trzy szczepy bakterii fermentacji mlekowej: Lactobacillus plantarum C3, Lactobacillus casei A4 i Lactobacillus delbrueckii D7 oraz zbadali ich przeżywalność podczas późniejszego przechowywania w temp. $4{ }^{\circ} \mathrm{C}$. Liczba komórek Lactobacillus casei A4 oraz Lactobacillus plantarum C3 po fermentacji wyniosła odpowiednio: 9,04 oraz 9,24 jednostek logarytmicznych w $1 \mathrm{ml}$. Analiza przeżywalności szczepów pozwoliła zaobserwować zamieranie Lactobacillus casei A4 już po 2 tygodniach przechowywania soku. Z kolei szczepy Lactobacillus plantarum C3 i Lactobacillus delbrueckii D7 odznaczały się lepszą przeżywalnością i po 4 tygodniach przechowywania liczba komórek wynosiła odpowiednio: 7,61 i 5,65 jednostek logarytmicznych w $1 \mathrm{ml}$ badanego soku. Ding i Shan [8] zbadali natomiast przeżywalność 8 szczepów (Lactobacillus rhamnosus, Bifidobacterium longum, Lactobacillus salivarius, Lactobacillus plantarum, Lactobacillus acidophilus, Lactobacillus paracasei, Bifidobacterium lactis typu Bi-04 i Bifidobacterium lactis Bi-07) w formie 
„wolnej” oraz mikrokapsułkowanej w soku jabłkowym i pomarańczowym, przechowywanych przez 6 tygodni w temp. $4{ }^{\circ} \mathrm{C}$. Liczbę komórek oznaczyli w interwałach tygodniowych, stosując metodę płytkową. Wyniki przeżywalności bakterii w obu sokach były zbliżone. Wymienieni autorzy wykazali, że w przypadku formy „wolnej” komórek wszystkie szczepy charakteryzowały się szybkim zamieraniem populacji. W soku pomarańczowym nie stwierdzono obecności żywych komórek po 4, a w soku jabłkowym - po 5 tygodniach przechowywania. W przypadku formy mikrokapsułkowanej komórek zaobserwowano wolniejsze zamieranie szczepów i w obu sokach oznaczono liczbę komórek kształtującą się na poziomie ok. 5 jednostek logarytmicznych w $1 \mathrm{ml}$ soku po 6 tygodniach przechowywania. Również Kocot i wsp. [15] zbadali przeżywalność Lactobacillus spp. w fermentowanych sokach warzywnych przechowywanych w temp. $6{ }^{\circ} \mathrm{C}$ przez 20 dni. Oznaczenia ilościowe wykonano metodami płytkową oraz barwienia fluorescencyjnego CFDA/PI (dioctan karboksyfluoresceiny/jodek propidyny). Barwienie umożliwiło zróżnicowanie populacji komórek Lactobacillus spp. na komórki żywe i martwe na podstawie aktywności wewnątrzkomórkowych esteraz (CFDA) oraz zachowania ciągłości błon cytoplazmatycznych (PI). Wykazano, że przeżywalność pałeczek Lactobacillus zależała od soku wybranego do fermentacji oraz od czasu przechowywania. W soku wielowarzywnym i pomidorowym rozwój populacji był bardziej intensywny niż w soku z buraków ćwikłowych. Sok buraczany powodował największe zmiany stanu fizjologicznego komórek. Kocot i wsp. [14] zbadali także przeżywalność Lactobacillus spp. w soku aloesowym przechowywanym przez 32 dni w temperaturze pokojowej. Liczebność populacji określono metodami płytkową oraz barwienia fluorescencyjnego LIVE/DEAD BacLight ${ }^{\mathrm{TM}}$ Viability Kit, które umożliwiło ocenę stanu fizjologicznego komórek pod względem spójności błon cytoplazmatycznych. Wyniki liczby Lactobacillus spp. oznaczone metodą płytkową dowiodły, że rozwój Lactobacillus spp. następował do 9. dnia przechowywania, a następnie liczba komórek zmniejszyła się do ok. 6,50 jednostek logarytmicznych w $1 \mathrm{ml}$ soku. Liczba komórek uzyskana z zastosowaniem zestawu LIVE/DEAD była najwyższa między 5. a 19. dniem i również utrzymała się na poziomie 6,50 jednostek logarytmicznych w $1 \mathrm{ml}$ do ostatniego dnia przechowywania, co wskazuje na dobrą przeżywalność pałeczek w soku aloesowym. Zatem badania dotyczące przeżywalności szczepów z rodzaju Lactobacillus stanowią ich pierwszą kwalifikację do produkcji soków z dodatkiem kultur probiotycznych. Dalszych badań wymaga jednak określenie prozdrowotności wybranego szczepu/soku oraz oceny atrakcyjności sensorycznej tego rodzaju produktu.

\section{Wnioski}

1. Zastosowanie metody fluorescencyjnej hybrydyzacji in situ (FISH) umożliwiło identyfikację pałeczek fermentacji mlekowej wyizolowanych z surowców pocho- 
dzenia roślinnego. Przynależność gatunkową określono w przypadku ośmiu z dziewięciu badanych szczepów.

2. Porównanie wyników metody FISH i metody płytkowej w badaniach aktywności fizjologicznej Lactobacillus spp. w soku z jagód goji pozwoliło na wykazanie przydatności metody FISH do tego rodzaju badań.

3. Temperatura przechowywania soku była czynnikiem, który znacząco wpływał na przeżywalność szczepów Lactobacillus spp. w soku z jagód goji. Różnice w liczebności populacji Lactobacillus spp. oznaczone w soku przechowywanym w temp. $20^{\circ} \mathrm{C}\left( \pm 2{ }^{\circ} \mathrm{C}\right)$ wskazują na utratę hodowalności przez komórki badanych szczepów.

Prace zaprezentowano podczas VII Sympozjum Naukowego „Probiotyki w żywności”. Kiry k. Zakopanego, 26 - 28.04.2017 r.

Badania finansowane $w$ ramach projektu $n$ r 2014/13/D/NZ9/04803 przez Narodowe Centrum Nauki oraz z funduszy na działalność statutowa (kod finansowy: 17.610.015-300) Katedry Mikrobiologii Przemysłowej i Żywności, Wydział Nauki o Żywności, Uniwersytet Warmińsko-Mazurski w Olsztynie.

\section{Literatura}

[1] Amagase H., Sun B., Borek C.: Lycium barbarum (goji) juice improves in vivo antioxidant biomarkers in serum of healthy adults. Nutr. Res., 2009, 29, 19-25.

[2] Amann R.I., Binder B.J., Olson R.J., Chisholm S.W.: Combination of 16S rRNA targeted oligonucleotide probes with flow cytometry for analysing mixed microbial populations. Appl. Environ. Microbiol., 1990, 56, 1919-1925.

[3] Ben Amor K., Vaughan E.E., de Vos W.M.: Advanced molecular tools for the identification of lactic acid bacteria. J. Nutr., 2007, 137, 741S-747S.

[4] Blasco L., Ferrer S., Pardo I.: Development of specific fluorescent oligonucleotide probes for in situ identification of wine lactic acid bacteria. FEMS Microbiol. Lett., 2003, 225, 15-123.

[5] Bogacz K.: Goji - owoc zdrowia i długowieczności. Przem. Ferm. Owoc. Warz., 2009, 9, 33-34.

[6] Coeuret V., Dubernet S., Bernardeau M., Gueguen M., Vernoux J.P.: Isolation, characterization and identification of lactobacilli focusing, mainly, on cheeses and other dairy products. Lait, 2003, 83, 269-306.

[7] De Vries M., Vaughan E., Kleerebezem M., De Vos W.: Optimising single cell activity assessment of Lactobacillus plantarum by fluorescent in situ hybridisation as affected by growth. J. Microbial. Meth., 2004, 59, 109-115.

[8] Ding W.K., Shan N.P.: Survival of free and microencapsulated probiotic bacteria in orange and apple juices. Int. Food Res. J., 2008, 15, 219-232.

[9] Ehrmann M., Ludwig W., Schleifer K.H.: Reverse dot blot hybridization: a useful method for the direct identification of lactic acid bacteria in fermented food. FEMS Microbiol. Lett., 1994, 117, 143-149.

[10] Ercolini D., Hill P.J., Dodd C.E.R.: Development of a fluorescence in situ hybridization method for cheese using a 16 rRNA probe. J. Microbiol. Meth., 2003, 52, 267-271.

[11] Hensiek R., Krupp G., Stackerbrandt E.: Development of diagnostic oligonucleotide probes for four Lactobacillus species occurring in the intestinal tract. Syst. Appl. Microbiol., 1992, 15, 123-128. 
[12] Hertel C., Ludwig W., Pot B., Kersters K., Schleifer K.H.: Differentiation of lactobacilli occuring in fermented milk products by using oligonucleotides probes and electrophoretic protein profiles. Syst. Appl. Microbiol., 1993, 16, 463-467.

[13] Jin M., Huang Q., Zhao K., Shang P.: Biological activities and potential health benefit effects of polysaccharides isolated from Lycium barbarum L. Int J. Biol. Macromol., 2013, 54, 16-23.

[14] Kocot A.M., Olszewska M.A., Gorywoda M., Łaniewska-Trokenheim Ł.: Ocena przeżywalności szczepów Lactobacillus spp. w funkcjonalnym soku aloesowym. W: Bezpieczeństwo zdrowotne żywności. Aspekty mikrobiologiczne, chemiczne i ocena towaroznawcza. Red. J. Stadnik, I. Jackowska. Wyd. Naukowe PTTŻ, Kraków 2015, ss. 67-76.

[15] Kocot A.M., Olszewska M.A., Błaszczyk M., Łaniewska-Trokenheim Ł.: Ocena przeżywalności pałeczek Lactobacillus spp. w fermentowanych sokach warzywnych przechowywanych chłodniczo. Zagadnienia aktualnie poruszane przez młodych naukowców 5. Red. M. Kuczera, K. Piech, Creativetime, Kraków 2016, ss. 20-23.

[16] Kulczyński B., Gramza-Michałowska A.: Kompleks polisacharydowy jagód goji (Lycium barbarum) jako element fitoterapii - przegląd literatury. Post. Fitoter., 2014, 4, 247-251.

[17] Lahtinen S., Gueimonde M., Ouwehand A., Reinikainen J., Salminen S.: Comparison of methods to enumerate probiotic bifidobacteria in a fermented food product. Food Microbiol., 2006, 23, 571-577.

[18] Oliver J.D.: The viable but nonculturable state in bacteria. J. Microbiol., 2005, 43, 93-100.

[19] Olszewska M.A, Kocot A.M., Łaniewska-Trokenheim Ł.: Physiological functions at single-cell level of Lactobacillus spp. isolated from traditionally fermented cabbage in response to different $\mathrm{pH}$ conditions. J. Biotechnol., 2015, 200, 19-26.

[20] Pereira A.L.F., Maciel T.C., Rodrigues S.: Probiotic beverage from cashew apple juice fermented with Lactobacillus casei. Food Res. Int., 2010, 44, 1276-1283.

[21] Qian J.Y., Liu D., Huang A.G.: The efficiency of flavonoids in polar extracts of Lycium chinense Mill fruits as free radical scavenger. Food Chem., 2004, 87, 283-8.

[22] Yoon K., Woodams E., Hang Y.: Production of probiotic cabbage juice by lactic acid bacteria. Biores. Technol., 2006, 97, 1427-1430.

[23] Young Yoon K., Woodams E.E., Hang Y.D.: Probiotication of tomato juice by lactic acid bacteria. J. Microbiol., 2004, 42, 315-318.

[24] Vogel R., Bocker G., Stolz P., Ehrmann M., Fanta D., Ludwig W., Pot B., Kersters K., Schleifer K.H., Hammes W.: Identification of lactobacilli from sour-dough and description of Lactobacillus pontis sp. nov. Int. J. Syst. Bacterial., 1994, 44, 223-239.

[25] Wallner G., Amann R., Beisker W.: Optimizing fluorescent in situ hybridisation with rRNA-targeted oligonucleotide probes for flow cytometric identification of microorganisms. Cytometry, 1993, 14, 136-143.

\title{
FLUORESCENT IN SITU HYBRIDIZATION APPLIED TO IDENTIFY AND EVALUATE PHYSIOLOGICAL ACTIVITY OF LACTOBACILLUS SPP. IN GOJI BERRY JUICE
}

\author{
S u m m a ry
}

Due to the popularization of the "Super Food" trend, consumers expect the presence in the market of products with a broad spectrum of impact on the human body. The goji berry juice is characterized by many beneficial properties, and enriching it with potentially probiotic strains of Lactobacillus spp. can further enhance its nutritional value provided the strains remain viable. The objective of the research study was to identify and evaluate the physiological activity of Lactobacillus spp. in goji berry juice using a fluorescent in situ hybridization (FISH) method. In order to identify Lactobacillus spp., the in situ hybridization was conducted with rRNA oligonucleotide probes including the domain-specific probe Eubacteria (Eub338), the nonsense probe (Non338), the probes specific for lactic acid bacteria (Lab158) group as well as 11 species-specific probes for different Lactobacillus species. The analysis of the physiological 
activity of Lactobacillus spp. cells in goji berry juice was carried out using the probe Eub338 immediately after the inoculation and on the $3^{\text {rd }}, 8^{\text {th }}, 15^{\text {th }}, 22^{\text {nd }}$, and $29^{\text {th }}$ day of storage at a $20{ }^{\circ} \mathrm{C}\left( \pm 2{ }^{\circ} \mathrm{C}\right)$ and at $6{ }^{\circ} \mathrm{C}$; the analysis results were compared with the results of the plate count method. The FISH method made it possible to determine the species where 8 out of 9 strains tested belonged to; those bacteria were classified as L. plantarum and L. brevis. In addition, it was proved that the physiological activity of the cells underwent significant changes resulting from storing the goji berry juice at a $20^{\circ} \mathrm{C}\left( \pm 2{ }^{\circ} \mathrm{C}\right)$, i.e. it decreased on the last day of storage. Comparing those results with the results of the plate method, the non-culturability of the cells may be suggested. However, after storing the juice at $6{ }^{\circ} \mathrm{C}$, its physiological activity was stable as the cell count was high until the last day of storage. Research conducted in this area indicates that the FISH method is useful for detecting and analyzing the physiology of Lactobacillus spp.

Key words: Lactobacillus spp., fluorescent in situ hybridization, identification, physiological activity 